ISSN 2077-1827. Гуманізація навчально-виховного процесу. 2020, №. 1 (99)

РОЗДІЛ. ВИЩА ШКОЛА

9. Chumicheva, R. (2010). Detstvo: nauchnyj fenomen i ego psihologopedagogicheskoe soprovozhdenie. Gumanizacija navchal'no-vihovnogo procesu: zbirnik naukovih prac'. 1. 286-291. [in Russian].

10. Fel'dshtejn, D.I. (1997). Social'noe razvitie v prostranstve - vremeni Detstva. M.: Moskovskij psihologo-social'nyj institut Flinta. [in Russian].

11. Bekh, I. (2003). Vykhovannia osobystosti: U 2 kn. Kn. 2: Osobystisnooriientovanyi pidkhid: naukovo-praktychni zasady. K.: Lybid. [in Ukrainian].

(англійською переклала І.Коротяєва - кандидат педагогічних наук, доцент кафедри германської та слов'янської філології Донбаського державного педагогічного університету).

\title{
УДК 37.015.311-053.4:796
}

\section{ЕНДЕБЕРЯ Ірина}

канд. психол. наук, доцент кафедри практичної психології, ДВНЗ «Донбаський державний педагогічний університет»

вул. Лозановича. 16, м. Слов'янськ, Донецька обл., Україна, 84112

E-mail: irina.endeberya2018@,gmail.com

\section{ШЛЯХИ ТА ЗАСОБИ ОРГАНІЗАЦІЇ САМОСТІЙНОЇ РОБОТИ СТУДЕНТІВ 3 УРАХУВАННЯМ Ї̈̈ ЗОВНІШНІХ ТА ВНУТРІШНІХ ПСИХОЛОГІЧНИХ ЧИННИКІВ}

Анотація. У статті розглядаються підходи до психологічного супроводу організації самостійної роботи студентів вищих навчальних закладів. Розкрито особливості організації самостійної роботи студентів та з'ясовано взаємозв'язок між: шляхи та засоби організації самостійної роботи студентів та урахуванням ії зовнішніх та внутрішніх психологічних чинників. Надається характеристика розвивальної програми, спрямованої на формування навичок та вмінь самостійної роботи, а також на розвиток особливостей мотиваційної та метакогнітивної сфер студентів. Розвиток метакогнітивної сфери містить серію занять, які сприяли розвитку пізнавальних якостей, які спрямовані на ефективну організацію самостійної роботи.

Розвивальна програма проходила у трьох напрямках, що полягають у роботі із психологом, роботі 3 викладачами та роботі із студентами, та складалася 3 декількох етапів. Основним напрямком була робота психолога зі студентами, метою якої був розвиток мотиваційних, та метакогнітивних якостей, які сприяють формуванню вміння продуктивно організовувати самостійну роботу; особливим напрямом була робота із викладачами, метою якої було оволодіння необхідних знань та формування відповідних навичок самостійної роботи у студентів. Не менш важливим напрямком $є$ робота із психологом,яка була спрямована на розвиток обізнаності у психологічних питаннях формування та оволодіння засобами розвитку мотиваційних, емоційно-вольових та когнітивних якостей, які сприяють формуванню вміння продуктивно організовувати самостійну роботу. Робота із психологом полягала в реалізації інформаційного та інструментального модулів.

Дана стаття $є$ практичною, тому що отримані у нашому дослідженні дані дозволяють робити систему заходів для формування навичок та вмінь самостійної

(C) Ендеберя I., 2020 
ISSN 2077-1827. Гуманізація навчально-виховного процесу. 2020, №. 1 (99)

РОЗДІЛ. ВИЩА ШКОЛА

роботи, а також розвитку особливостей мотиваційної та метакогнітивної сфер студентів, які сприяли би підвищенню ефективності їх самостійної роботи.

Ключові слова: самостійна робота, організація самостійної роботи, навчальна діяльність студентів, психологічні чинники, студент.

Постановка проблеми у загальному вигляді та її зв'язок 3 важливими науковими чи практичними завданнями. Раціональна організація самостійної роботи студентів - один із резервів вдосконалення вищої освіти. Вона забезпечує якість навчання, економію учбового часу, високу результативність освіти.

Самостійна робота як провідна та вища форма навчальної діяльності студентів у виші забезпечується високим рівнем їх пізнавальної діяльності. Якість та зміст пізнавальної активності говорить про суб'єкт-субєктний характер навчання у вищому навчальному закладі. До показників результативності навчальної діяльності студента як суб'єкта навчальної діяльності відносяться не тільки знання, вміння та навички, а й мета знання (вміння вчитися). Самостійно оволодівати знаннями без спеціального навчання неможливо, такому виду діяльності слід навчати.

Аналіз останніх досліджень і публікацій. За даними досліджень С.А. Пакуліної [4], 52\% студентів другого курсу та 29\% студентів першого курсу вказують на відсутність вміння працювати самостійно. Таким чином, можна стверджувати про різний ступінь вміння суб' єктом учитися. Науковець зазначає, що не тільки першокурсники недостатньо володіють раціональними навичками діяльності: культурою роботи з книгою, технікою конспектування, засвоєнням та запам'ятовуванням прочитаного; а також студенти старших курсів не вміють економити час, планувати роботу, тому необхідно створити певні умови для навчання самостійній роботі ще на першому курсі.

Авторська програма навчання самостійні роботі студентів, запропонована С.А. Пакуліною, включає:

- вивчення теоретико-методологічних основ самостійної роботи студентів як провідної форми навчальної діяльності;

- діагностику студентами власної пізнавальної потреби у розширенні, поглибленні знань, отриманих у вузі;

- діагностику самостійності як особистісної якості;

- розробку конкретного плану довгострокової та ближньої програми самостійної діяльності;

- навчання конспектуванню;

- підготовку студентів до науково-дослідницької діяльності.

Одним з компонентів організації самостійної роботи студентів є навчання навичкам планування часу. На думку дослідниці Т.Н. Козловської [3], найбільш суттєвим періодом в усвідомленні цінності часу, важливості управління часом виступає студентський вік. Самоорганізація часу $є$ одним 3 найважливіших факторів, які впливають на формування образу майбутнього, тому протягом університетського навчання необхідно надавати велику увагу озброєнням студентів стратегією і тактикою самоменеджменту.

Виявлений Т.Н. Козловською низький рівень засвоєння студентами методів самоорганізації дозволив створити автором спецкурс «Самоорганізація часу студентів». У розробленому автором спецкурсі використовувались такі форми роботи зі студентами, як лекції, практичні заняття, ігри, тренінги. Розвивальна програма, запропонована Т.Н. Козловською, містить емоційний, організаційний та цілепокладальний компоненти, що на наш погляд, не $\epsilon$ 
ISSN 2077-1827. Гуманізація навчально-виховного процесу. 2020, №. 1 (99)

РОЗДІЛ. ВИЩА ШКОЛА

достатнім для формування навичок планування часу як комплексної психологічної властивості.

На думку дослідниці С.В. Чебровської [1;5], розвиток самостійності вимагає створення системи зовнішніх та внутрішніх умов, які представляють собою групи умов когнітивного, особистісного та діяльнісного змісту. Психологічними механізмами оволодіння самостійністю $\epsilon$ можливість свобідного вибору, усвідомлена цілеспрямованість діяльності та персональна відповідальність за результат. Формування самостійності студентів, на думку автора, забезпечується через реалізацію особистісно-діяльнісної моделі навчання, основаної на принципах розвивального навчання, яка дозволяє студенту усвідомити свої особистісні ресурси та активізувати їх, більш глибоко зрозуміти особливості ефективності діяльності, засвоїти необхідні професійні норми. Під час засвоєння експериментальної моделі навчання підвищується рівень самостійності студентів.

Проблемою формування творчої самостійності студентів займалися Л.П. Качалова, Д.В. Качалов, А.В. Качалов [2]. Для ефективного функціонування технології формування творчою самостійністю майбутнього вчителя Л.П. Качалова, Д.В. Качалов, А.В. Качалов виявили наступні психолого-педагогічні умови:

- залучення студентів до різноманітних форм та видів творчої діяльності, яке передбачає, що студенти включені у навчально- пізнавальну діяльність, пов'язану з творчими пошуками та створенням творчого результату;

- збагачення змісту освіти прийомами та методами, які мають вплив на мотиваційну, вольову, емоційну та діяльнісну сфери особистості: рефлексивностимулюючі, мотиваційно-стимулюючі, діяльнісно-організаційні;

- включення до навчально-пізнавального процесу творчих завдань, які формують творчу самостійність студентів: завдання на рефлексивну здогадку, творчу інтерпретацію, тощо.

Дослідник В.В. Усманов [5] в результаті теоретико-експериментальної роботи 3 дослідження самостійної роботи студентів визначив можливості реалізації задач сучасної освіти шляхом об'єднання психолого-педагогічних, акмеологічних та соціальних факторів, засобів та умов, серед яких найбільш значущими є:

- формування компонентів та механізмів самостійної роботи студентів, яке реалізується в освітньому просторі, психологічною основою, умовою розвитку якого виступають творче мислення, професійне самовизначення, самоосвіта та самовиховання студентів як суб'єктів навчального процесу;

- адаптований зміст професійної освіти, який у своїй фундаментальній та практичній складових спрямований на зміни у науці, техніці, технологіях, а також на строки втілення таких перетворень у виробництво та практику;

- динаміка розвитку кожного компоненту самостійної роботи студентів забезпечується системним процесом самовдосконалення, складовими якого $є$ з'єднані теоретична та практична підготовка, індивідуалізація навчання за допомогою електронних навчальних завдань;

- інтенсифікація управління самостійною роботою студентів, яка спирається на логіку суб'єктивного розвитку особистості студента, активність його психічних процесів, ціннісно-змістовну сферу, професійно-особистісний потенціал, відповідальність у співвідношенні 3 процесом професійного самовизначення; 
ISSN 2077-1827. Гуманізація навчально-виховного процесу. 2020, №. 1 (99)

РОЗДІЛ. ВИЩА ШКОЛА

- ефективність професійної підготовки спеціаліста, творчого розвитку напрямів його діяльності залежить від рівня сформованості самостійної роботи студентів.

Формулювання цілей статті. Мета статті - визначення шляхів та засобів організації самостійної роботи студентів та її психологічні чинники.

Виклад основного матеріалу дослідження. Як відзначалося вище, психологічний супровід ефективної організації самостійної роботи студентів $\epsilon$ серйозною психологічною проблемою. Для ії рішення розроблено і впроваджено ряд заходів. У зв'язку з цим ми намагалися розробити диференційовану розвивальну програму, яка б зробила ефективний вплив як на студентів, так і на викладачів у їх взаємодії в процесі навчальної діяльності.

Метою розвивальної програми $є$ розвиток особливостей мотиваційної та метакогнітивної сфер особистості студентів, які б сприяли формуванню навичок та вмінь ефективної самостійної роботи.

В процесі реалізації розвивальної програми робота проводилась за такими напрямками:

- основним напрямком була робота психолога зі студентами, метою якої був розвиток мотиваційних, та метакогнітивних якостей, які сприяють формуванню вміння продуктивно організовувати самостійну роботу;

- особливим напрямом була робота із викладачами, метою якої було оволодіння необхідних знань та формування відповідних навичок самостійної роботи у студентів.

- не менш важливим напрямком $є$ робота із психологом, спрямована на розвиток обізнаності у психологічних питаннях формування та оволодіння засобами розвитку мотиваційних, емоційно-вольових та когнітивних якостей, які сприяють формуванню вміння продуктивно організовувати самостійну роботу.

Таким чином, розвивальна програма проходила у трьох напрямках, що полягають у роботі із психологом, роботі з викладачами та роботі із студентами, та складалася 3 декількох етапів. Зупинимось коротко на характеристиці кожного з етапів розвивальної програми.

Робота із студентами реалізується наступними етапами.

1. Мотиваційний етап:

Мета даного етапу полягала у:

- забезпеченні позитивної мотивації до участі в розвивальній програмі через ознайомлення з їі метою та змістом;

- забезпеченні позитивної мотивації до участі в розвивальній програмі через ознайомлення 3 мотивацією керівника розвивальної програми, яка спричинила іiі створення та впровадження.

- формуванні позитивного психологічного клімату тренінгової групи;

- формування установки на необхідність оволодіння методами, прийомами та засобами ефективної організації самостійної роботи та продуктивного планування часу.

Актуалізація мотивації до певної діяльності (у нашому випадку участі у розвивальній програмі) має бути пов'язана 3 основними мотивами, які притаманні студентам. Усвідомлюючи те, що основні прагнення, бажання, інтереси можуть бути реалізовані через участь в розвивальних заняттях, студент оволодіває позитивною мотивацією до зазначених занять. Серед основних мотивів студентів, які були застосовані нами в першому модулі розвивальної програми були такі, що найчастіше зустрічаються у студентському віці: 
ISSN 2077-1827. Гуманізація навчально-виховного процесу. 2020, №. 1 (99)

РОЗДІЛ. ВИЩА ШКОЛА

можливість підвищення власної самоефективності, навчальної успішності, економії часових ресурсів, розвиток пам'яті, уважності, творчих здібностей, оволодіння засобами раціонального читання.

Разом 3 тим, ознайомлення зі змістом (тих блоків, які спрямовані на формування певних вмінь та навичок) i передбачуваними результатами (формуванням конкретних навичок та вмінь, підвищення навчальної успішності, економія часу, витраченого на навчання) для розвивальної програми формує конкретне детальне уявлення про те, що являє собою розвивальна програма і на що вона спрямована. Дане уявлення, якщо воно зрозуміле і прийнятне для студентів також може стати компонентом позитивної мотивації. Ознайомлення студента 3 мотивацією керівника розвивальної програми, з історією виникнення його інтересу, з повідомленням причин того, чому він створив і впроваджує розвивальну програму в життя також є побічним засобом позитивної мотивації в учасників програми.

2. Метакогнітивний етап:

Метою даного етапу було:

- усвідомлення особливостей власної пізнавальної сфери, які сприяють ефективній організації самостійної роботи;

- розвиток уважності як когнітивної особливості особистості, що сприяє ефективній самостійній роботі у навчальній діяльності;

- формування вміння застосовувати мнемотехніки та прийоми ефективного запам'ятовування в організації власної самостійної роботи;

- розвиток творчих здібностей, що сприяють ефективній організації самостійної роботи;

- формування вміння ефективного читання як засобу успішної організації самостійної роботи;

- усвідомлення результатів розвивально-корекційних впливів даного модулю та можливостей їх застосування в житті.

Метакогнітивний етап містить серію занять, які сприяли розвитку пізнавальних якостей, які спрямовані на ефективну організацію самостійної роботи. Когнітивний етап містить такі стадії: перша стадія спрямована на усвідомлення особливостей власної пізнавальної сфери, які сприяють ефективній організації самостійної роботи; друга стадія спрямована на формування вміння застосовувати мнемотехніки та прийоми ефективного запам'ятовування в організації власної самостійної роботи; третя стадія спрямована на розвиток творчих здібностей, що сприяють ефективній організації самостійної роботи; четверта стадія спрямована на формування вміння ефективного читання як засобу успішної організації самостійної роботи; п’ята стадія спрямована на усвідомлення результатів розвивально-корекційних впливів даного модулю та можливостей їх застосування в житті.

Робота із психологом полягала в реалізації інформаційного та інструментального модулів.

1. Інформаційний етап:

Метою інформаційного етапу виступили:

- розвиток обізнаності у психологічних питаннях щодо активізації позитивної мотивації до участі у розвивальній програмі;

- розвиток обізнаності у психологічних особливостях формування тренінгової групи; 
ISSN 2077-1827. Гуманізація навчально-виховного процесу. 2020, №. 1 (99)

РОЗДІЛ. ВИЩА ШКОЛА

- розвиток обізнаності у психологічних питаннях вікових особливостей особистості студентів;

- розвиток обізнаності у психологічних чинниках організації самостійної роботи студентів;

- розвиток обізнаності у психологічних питаннях мотиваційних особливостей студентів; студентів.

- розвиток обізнаності у психологічних питаннях пізнавальної сфери

2. Інструментальний етап:

Метою інструментального етапу було:

- оволодіння засобами активізації позитивної мотивації до участі у розвивальній програмі;

- оволодіння засобами створення позитивного психологічного клімату у тренінговій групі;

- оволодіння засобами розвитку мотиваційних особливостей студентів, які сприяють ефективній організації самостійної роботи;

- оволодіння засобами розвитку пізнавальної сфери студентів, що сприяють ефективній організації самостійної роботи.

Робота із викладачами також полягала в реалізації інформаційного та інструментального етапів.

Метою інформаційного етапу було:

- розвиток обізнаності в психологічних питаннях організаторських здібностей щодо регулювання самостійної роботи студентів;

- розвиток обізнаності в психологічних питаннях вікових особливостей особистості студентів;

- розвиток обізнаності в особливостях організаційної культури вищого навчального закладу.

Метою інструментального етапу було:

- оволодіння засобами активізації уваги у студентській групі;

- оволодіння засобами розвитку самостійності студентів;

- оволодіння засобами розвитку пізнавальних навичок, що сприяють ефективності самостійної роботи для ефективної організації самостійної роботи.

Висновки 3 даного дослідження і перспективи подалышого розвитку у даному напрямку. Отримані у нашому дослідженні дані дозволяють робити систему заходів для формування навичок та вмінь самостійної роботи, а також розвитку особливостей мотиваційної та метакогнітивної сфер студентів, які сприяли би підвищенню ефективності їх самостійної роботи.

Перспективою нашого дослідження виступить перевірка ефективності зазначеної розвивальної програми.

\section{СПИСОК ВИКОРИСТАНОЇ ЛІТЕРАТУРИ}

1. Мамаев В.А. Аксиологический подход в воспитании студенчества Вестник ЮУрГУ. 2012. № 41. С. 134-136. Режим доступа: https://cyberleninka.ru/article/n/aksiologicheskiy-podhod-v-vospitaniistudenchestva.

2. Качалова Л.П., Качалов Д.В., Качалов А.В. Технология формирования творческой самостоятельности у студентов педвуза Современные проблемы науки и образования. 2009. № 6. С. 52-53. 
ISSN 2077-1827. Гуманізація навчально-виховного процесу. 2020, №. 1 (99)

РОЗДІЛ. ВИЩА ШКОЛА

3. Козловская Т.Н. Обучение студентов навыкам планирования времени Психология в вузе. 2007. №4. С. 37-46.

4. Пакулина С.А. Педагогика и психология самостоятельной работы студентов в высшей школе. Челябинск, 2007. 190 с.

5. Усманов В.В. Самостоятельная работа студентов: организация и управление в процессе теоретического обучения. Ульяновск, 2006. 278 с.

Стаття надійшла до редакції 20.12.2019.

\section{ЭНДЕБЕРЯ Ирина}

канд. психол. наук, доцент кафедры практической психологии ГВУЗ Донбасский государственный педагогический университет (г. Славянск, Украина)

ул. Г. Лозановича, 16, г. Славянск, Донецкая обл., Украина, 84112

E-mail: irina.endeberya2018@gmail.com

\section{ПУТИ И СРЕДСТВА ОРГАНИЗАЦИИ САМОСТОЯТЕЛЬНОЙ РАБОТЫ СТУДЕНТОВ С УЧЕТОМ ЕЁ ВНЕШНИХ И ВНУТРЕННИХ ПСИХОЛОГИЧЕСКИХ ФАКТОРОВ}

Резюме. В статье рассматриваются подходы к психологическому сопровождению организации самостоятельной работы студентов высших учебных заведений. Дается характеристика развивающей программы, направленной на формирование навыков и умений самостоятельной работы, а также развитие особенностей мотивационной и метакогнитивной сфер студентов. Развитие метакогнитивной сферы студентов включает серию занять, которые способствуют развитию познавательных качеств, направленных на эффективную организацию самостоятельной работы.

Развивающая программа проходила по трем направлениям, которые заключаются в работе с психологом, работе с преподавателями и работе со студентами, и состояла из нескольких этапов. Основным направлением была работа психолога со студентами, целью которой было развитие мотивационных, и метакогнитивные качеств, которые способствуют формированию умения продуктивно организовывать самостоятельную работу; особым направлением была работа с преподавателями, целью которой было овладение необходимых знаний и формирование соответствующих навыков самостоятельной работы студентов.

Не менее важным направлением является работа с психологом, которая была направлена на развитие осведомленности в психологических вопросах формирования и овладения средствами развития мотивационных, эмоциональноволевых и когнитивных качеств, которые способствуют формированию умения продуктивно организовывать самостоятельную работу. Работа с психологом заключалась в реализации информационного и инструментального модулей.

Данная статья является практической, так как полученные в нашем исследовании данные позволяют разработать систему примов по формированию навыков и умений самостоятельной работы, а также развития особенностей мотивационной и метакогнитивные сфер студентов, которые способствовали бы повышению эффективности их самостоятельной работы.

Ключевые слова: самостоятельная работа, организация самостоятельной работи, учебная деятельность студентов, психологические причины, студент. 


\section{ENDEBERYA Irina}

kand. psychological sciences, associate professor of practical psychology of the State Pedagogical University of Donbas (Slavyansk, Ukraine)

16 G. Lausanovich str., Slavyansk, Donetsk Region, Ukraine, 84112

E-mail: irina.endeberya2018@gmail.com

\section{THE WAYS AND MEANS OF STUDENT'S UNASSISTED WORK'S ORGANIZATION SUBJECT TO ITS INTERNAL AND EXTERNAL FACTORS}

Summary. Approaches to psychological support of the organization of independent work of students of higher educational institutions are considered in the article. The peculiarities of organizing students 'independent work are revealed and the relationship between: ways and means of organizing students' independent work and taking into account its external and internal psychological factors are clarified. The characteristic of the developmental program aimed at forming the skills and abilities of independent work, as well as the development of peculiarities of students' motivational and metacognitive spheres is given.

Keywords: «unassisted work of students», «organization of student's unassisted work», «student's educational activities», psychological reasons, student.

Abstract. Introduction. We examine psychological approaches to advance the organization of student's unassisted work. The characteristics of program, which is directed to advance skills and abilities of unassisted work, to the features of motivational and metacognitive spheres, are given.

Analysis of publications. L.P. Kachalova, D.V. Kachalov, A.V. Kachalov dealt with a problem of formation of creative independence of students. For effective functioning of technology of formation by creative independence of future teacher L.P. Kachalov, D.V. Kachalov, A.V. Kachalov found the following psychology and pedagogical conditions: nvolvement of students to different forms and types of creative activity which provides that students are included in uchebno - cognitive activity, $p$ "a yazana with creative search and creation of creative result; enrichments of content of education receptions and by methods which have influence on motivational, strong-willed, emotional and the activity sphere of the personality: reflexively stimulating, motivational stimulating, actively organizational; inclusion in uchebno informative process of creative tasks which form creative independence of students: Tasks on reflexive a guess, creative interpretation, and so forth.

Purpose. Article purpose - definition of ways and means of the organization of independent work of students and its psychological factors.

Results. As it was noted above, psychological support of the effective organization of independent work of students is a serious psychological problem. For its decision a number of actions is developed and introduced. In this regard we tried to develop the differentiated developing program which would make effective influence both on students, and on teachers in their interactions in the course of educational activity.

The purpose of the developing program is development of features motivational and metakogn tivno $\ddot{i}$ spheres of the identity of students which would promote formation of skills and abilities of effective independent work.

Conclusion. The data obtained in our research allow to do the system of actions for formation of skills and abilities of independent work and also development of features motivational and metakogn_tivno ï spheres of students which would promote 
ISSN 2077-1827. Гуманізація навчально-виховного процесу. 2020, №. 1 (99)

РОЗДІЛ. ВИЩА ШКОЛА

increase in efficiency of their independent work. Check of efficiency of the specified developing program will act as prospect of our research.

\section{REFERENCES}

1. Mamaev V.A., (2012). Aksiologicheskiy podkhod v vospitanii studenchestva [Axiological approach in the education of students] Retrieved from https://cyberleninka.ru/article/n/aksiologicheskiy-podhod-v-vospitaniistudenchestva [in Russian].

2. Kachalova L.P., Kachalov D.V., Kachalov A.V. (2009). Tekhnolohyia formyrovanyia tvorcheskoi samostoiatelnosty u studentov pedvuza [in Russian].

3. Kozlovskaia T.N., (2007). Obuchenye studentov navыkam planyrovanyia vremeny // Psykholohyia v vuze [in Russian].

4. Pakulyna S.A., (2007). Pedahohyka y psykholohyia samostoiatelnoi rabotbl studentov v vblsshei shkole. Chelyabinsk. [in Russian].

5. Usmanov V.V., (2006). Samostoiatelnaia rabota studentov: orhanyzatsyia y upravlenye v protsesse teoretycheskoho obuchenyia. Ulyanovsk. [in Russian].

(англійською переклала С. Рижкова - викладач іноземних мов ДДПУ)

\section{УДК 373.2.015.31:316.614.032:33}

\section{КУРІННИЙ Ян}

Канд. пед наук, доцент кафедри дошкільної освіти та соціальної роботи, ДВНЗ „Донбаський державний педагогічний університет”

пров. Вчительський 1, м. Слов'янськ, Донецька обл., Україна, 84110

E-mail: yankurinnoy@gmail.com

\section{ТЕОРЕТИЧНИЙ АНАЛІЗ ПЕРВИННОЇ ЕКОНОМІЧНӦ̈ СОЦІАЛІЗАЦЇ̈ ДОШКІЛЬНИКІВ}

Анотація. У даній статті наданий глибокий теоретичний аналіз феномену „економічна соціалізація дошкільників”. Теоретичний аналіз економічної соціалізації здійснено в межах загальної теорії соціалізації. Нас цікавили, насамперед, питання щодо функцій, чинників i механізмів соціалізації особистості, оскільки саме вони є ключовими теорії соціалізації й за допомогою них ми змогли дослідити аналогійні моменти теорії економічної соціалізації.

Окреслено величезний інтерес науковців до проблеми соціалізації особистості. Аналіз досліджень соціалізації особистості дозволив визначити низку iii функцій, які детерміновані чинниками та механізмами соціалізації. Найбільш „сталими” можна назвати функції інкультурації та трансляції культури, оскільки культурне середовище, з одного боку, акумулює соціально значущі результати діяльності людей, а з іншого - їх взаємодію 3 предметами культури, що призводять до формування соціальної свідомості особистості. Найбільш дослідженими функціями соціалізації особистості можна вважати функцію засвоєння (інтеріоризації) соціального досвіду. Систематизовано психологічні механізми соціалізації особистості як процесу, який перетворює активність чинника соціалізації (соціальні умови, рушійні сили, якості особистості) в ऑiі результат. Розкрито багатоаспектний зв'язок економічної свідомості, економічних цінностей, економічної поведінки: те, що за одних умов і за одних обставин постає як причина, в інших виявляється наслідком.

(C) Курінний Ян., 2020 